\title{
Diagnosis of Fibrinolytic Hemorrhage
}

\author{
By \\ Shinryo Shinagawa, Masahiro Maki, Iwao Kikuchi, \\ Kazuma Nagasawa and Atsushi Takano

\section{From the Department of Obstetrics and Gynecology, Faculty of Medicine, Hirosaki University, Hirosaki}

(Received for publication, April 1, 1964)

\begin{abstract}
It is unusual to be able to obtain blood samples for laboratory examination from patients with fibrinolytic hemorrhage prior to the manifestation of bleeding. Therefore, some of the results obtained from laboratory tests may represent secondary changes due to fibrinolytic hemorrhage. In order to detect valuable diagnostic tools, the various tests for clotting and plasmin systems were carried out on 16 patients diagnosed as having fibrinolytic hemorrhage and on plasma in which fibrinolysis was artificially induced by streptokinase addition in vitro. The importance of measurements of clot-lysis time of the whole blood and whole plasma, prothrombin activity, thrombelastography, heparin tolerance test, fibringogen, factors of plasmin system, thrombin time, fibrinogen by turbidometric method and erythrocytes sedimentation rate in cases of pregnancy was emphasized as diagnostic tools of fibrinolytic hemorrhage, especially the latter three due to their simplicity in technique.
\end{abstract}

The term "fibrinolytic hemorrhage" in this paper is applied to the hemorrhage associated with enhanced fibrinolytic activity in the circulating blood. This includes, of course, fibrinolytic purpura, thrombolytic purpura and acquired fibrinolytic hypofibrinogenemia, but excludes the hemorrhage due to elevated local fibrinolysis which does not accompany detectable change of plasmin system in the circulating blood.

A hemorrhagic diathesis due to enhanced fibrinolytic activity is sometimes a life-threatening condition, especially in cases with hypofibrinogenemic state. However, if the correct and early diagnosis is made, and such rational therapeutic procedures as administration of epsilon aminocaproic acid is undertaken and, if necessary, fibrinogen or fresh blood is given to the patient, the fibrinolytic hemorrhage does not seem to be so hazardous.

In actual clinical cases, it is very rare to be able to obtain and examine blood

品川信良, 真木正博, 菜池岩男, 高沢一磨, 高野 敦

The 11th report of Pathophyisology of Plasmin System 
samples from patients with fibrinolytic hemorrhage during the process of elevation of fibrinolysis or before the manifestation of the hemorrhage. The majority of blood samples are from patients who have already bled or following initiation of therapeutic procedures. It is, therefore, uncertain whether the laboratory tests of blood samples are due to etiologic factors or are secondary changes of the condition.

In this paper, various analyses for the clotting and plasmin systems are performed on the artificially activated plasma by addition of streptokinase (SK), and the results are compared with those of actual cases of fibrinolytic hemorrhage.

\section{MATERIALS AND METHODS}

Blood plasma is obtained by centrifuging (3000 r.p.m. for 10 minutes) a mixture of 1 vol. of $3.8 \%$ sodium citrate and 9 vol. of venous blood from patients with fibrinolytic hemorrhage who are listed in Table $I$. The following tests are performed for the analyses:

1. Clotting time and clot-lysis time of the whole blood ${ }^{1)}$

2. Bleeding time by Duke

3. Platelet count by Fonio-Sahli or Rees-Ecker

4. Prothrombin time by Quick's one stage method

5. Prothrombin activity by TAMe-lytic method of Glueck et al. ${ }^{2}$ )

6. Thrombotest by Owren

7. Thrombin time by Hougie ${ }^{3)}$

8. Thrombelastography by Hartert

9. Partial thromboplastin time by Thrombofax test ${ }^{4)}$

10. Recalcification time

11. Heparin tolerance test

A tube containing $5 \mathrm{ml}$. of heparin (1 unit) in $1 / 40 \mathrm{M}$ calcium chloride was incubated at $37^{\circ} \mathrm{C}$ for 5 minutes. To the tube, $0.5 \mathrm{ml}$. of plasma was added and then the clotting time was measured. As a control, the same test was also carried out in the absence of heparin.

12. Plasma fibrinogen titer (PFT) and fibrinolysis level1)

13. Fibrinogen

Fibrinogen of the patient's blood was determined by phenol reagent on thrombin-clotted fibrin ${ }^{5}$, and fibrinogen of experimentally induced fibrinolytic plasma was measured by a turbidometric method of Parfentjev at el. ${ }^{6}$ )

14. Spontaneous caseinolytic, fibrinolytic and fibrinogenolytic activities of euglobulin fraction?)

15. Total plasmin?)

16. Antiplasmin ${ }^{8}$

17. Erythorcytes sedimentation rate (ESR) by Westergren's method 


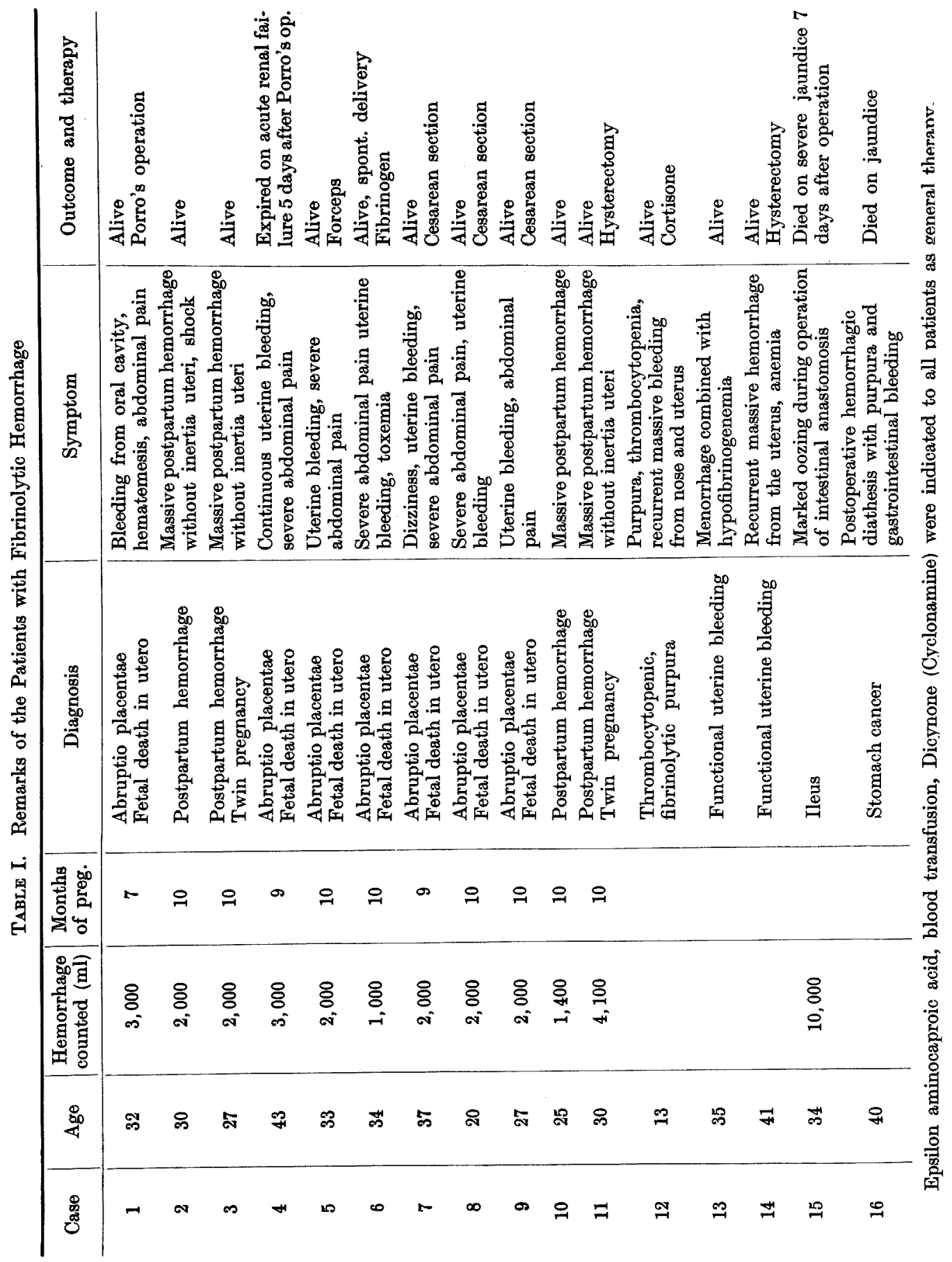




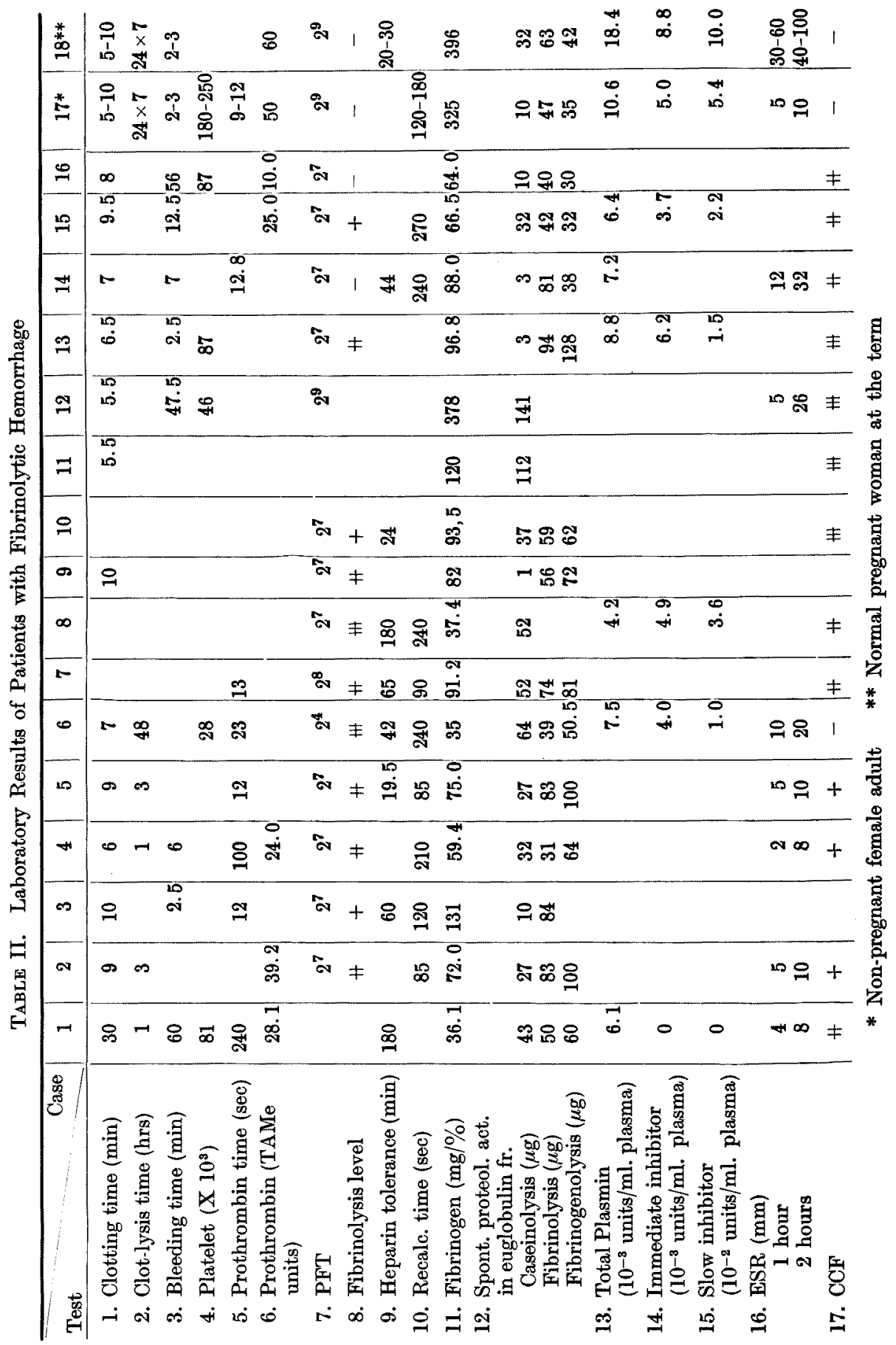


18. Cephalin-cholesterol flocculation (CCF) test by Hanger ${ }^{9)}$

In order to obtain various grades of induced fibrinolysis in vitro, the following procedure was performed on plasma.

To each tube containing $25 \mathrm{ml}$. of citrated plasma, various amounts of SK were added to make the final concentration of $400,200,25,5,1$ and $\mathrm{O}$ SK-units per ml. of plasma, and then kept at $25^{\circ} \mathrm{C}$. The determinations of clotting and plasmin systems were performed on the above activated plasma at various intervals of time.

\section{RESULTS AND DISCUSSION}

The results are summarized in Tables II, III and IV.

1. Clotting time and clot-lysis time of whole blood

The determination of clotting time of the whole blood has been regarded as an important diagnostic step in hypofibrinogemia. However, prolongation of the clotting time was noted in only 1 of 13 cases. This one case had $36.1 \mathrm{mg} \%$ fibrinogen. In authors' experience, prolongation of the clotting time seems to occur when fibrinogen concentration becomes $50 \mathrm{mg} \%$, or perhaps $30 \mathrm{mg} \%$, or less. In general, there is a tendency for the clotting time to shorten when bleeding begins from any site. It is, therefore, a part phenomenon of the general alarm reaction. Deutsch and Elsner ${ }^{10}$ ) noted that the hypercoagulability which is characterized by shortening of the clotting time of whole blood, heparin tolerance test and reaction time in the thrombelastogram, is apparently a general side reaction of proteolytic enzyme. This may be detectable when the concentration of proteolytic enzyme is too small to induce effective fibrinolysis. Therefore, the determination of clotting time as a diagnostic tool in hypofibrinogenemia or fibrinolytic hemorrhage does not seem to be valuable as is generally believed. Moreover, since incoagulability of the blood in obstetric patients may also be due to an acquired circulating anticoagulant ${ }^{11,12}$, simple clotting time of the whole blood cannot be a specific test for hypofibrinogenemia. It is important to observe a nature of blood clot which is much smaller and softer than a normal clot and rapidly dissolves. In 5 of 5 cases, the clot was spontaneously lysed within 48 hours. However, a markedly delayed clotting time, of course, suggests the presence of a severe coagulation defect one of which is hypofibrinogenemia.

\section{Bleeding time}

In cases of fibrinolytic hemorrahge, it was markedly prolonged (48-60 min.) in 3 of 8 . Hsu et al. ${ }^{13)}$ reported that in 2 of 8 cases of hypofibrinogenemia (lower than $100 \mathrm{mg} \%$ fibrinogen) occurring in abruptio placentae, the bleeding time was over 10 minutes. The measurement of bleeding time seems to be more 
important for the decision of management of the patient rather than for diagnosis. Namely, when the patient's bleeding time shows a marked prolongation, such active treatments as cesarean section, artificial induction of labor and other surgical operations may be contraindicated, because the condition results in a massive uncontrollable hemorrhage from the newly formed wounds. Therefore, such active treatments would only be indicated after improvement of the bleeding time.

\section{Platelets}

In all 5 cases, platelets were decreased. The same tendency was noted by Hsu et $a l_{.}{ }^{13)}$ and Sharp et $a .^{14)}$ in cases of hypofibrinogenemia with abruptio placentae and by Firkin et al. $\left.{ }^{15}\right)$ in cases of fibrinolytic hemorrhage. Johnson and Schneider ${ }^{16}$ ) reported that $70 \%$ of antiplasmin in the blood is from platelet origin, and concluded that enhancement of fibrinolysis is an expression of thrombocytopenic state. However, this conclusion cannot be given solid support, because the enhancement of fibrinolysis does not always occur in cases of essential thrombocytopenia. Ikami et al. ${ }^{17}$ ) noted that the elevation of fibrinolytic activity causes the destruction of platelets. The consumption of platelets in the hemostatic process, consumption due to blood loss, platelet agglutination ${ }^{18)}$ and centralization of blood cells as well as platelets into the splanchnic area in cases of hemorrhagic shock may also be causative factors of thrombocytopenia. Anyhow, one should determine the platelet count when elevated fibrinolytic activity is observed, and conversely, fibrinolytic activity should be determined when a thrombocytopenic state is noted.

\section{Prothrombin time and thrombotest}

It is generally said that such clotting factors as fibrinogen, prothrombin, factors V and VIII decrease in case of pathologic fibrinolytic state. Accordingly, the prothrombin time by Quick's one stage method and clotting time by Owren's thrombotest must be theoretically prolonged. In fact, a prolonged prothrombin time was observed in 3 of 7 cases.

\section{Prothrombin activity by TAMe-lytic method}

The prothrombin activity was decreased to 10-39.2 TAMe units in all 6 cases, while the normal activity of pregnant women at the term averaged 63.5 TAMe units ${ }^{19)}$. However, as the method is complicated and time-consuming, it does not seem to be suitable for clinical testing in spite of its sensitivity.

6. Partial thromboplastin time by Thrombofax test

As the partial thromboplastin time of Landgell et $a l_{.}^{20)}$ is said to be sensitive to a decrease of factors I, II, V, VIII, IX, X and XI, and to be useful for the identification of patients who are actual risks of hemostatic 
TABLE III. Changes of Various Clotting Tests after Addition of SK to Plasma

\begin{tabular}{|c|c|c|c|c|c|}
\hline \multirow{2}{*}{ Test } & \multirow{2}{*}{$\begin{array}{r}\text { SK added } \\
\text { (units } / \mathrm{ml} \text { ) }\end{array}$} & \multicolumn{4}{|c|}{ Hours examined after SK addition } \\
\hline & & 1 & 2 & 3 & 4 \\
\hline $\begin{array}{l}\text { Prothrombin time } \\
\text { (sec) }\end{array}$ & $\begin{array}{r}400 \\
200 \\
25 \\
0\end{array}$ & $\begin{array}{r}13.8 \\
11.2 \\
9.8 \\
10.8\end{array}$ & $\begin{array}{l}13.0 \\
11.5 \\
10.5 \\
11.0\end{array}$ & $\begin{array}{l}19.8 \\
18.0 \\
11.2 \\
11.4\end{array}$ & $\begin{array}{l}19.6 \\
16.2 \\
11.5 \\
11.5\end{array}$ \\
\hline $\begin{array}{r}\text { Thrombotest } \\
\text { (sec) }\end{array}$ & $\begin{array}{r}400 \\
200 \\
25 \\
0\end{array}$ & $\begin{array}{l}38.0 \\
41.0 \\
39.0 \\
37.0\end{array}$ & $\begin{array}{l}32.0 \\
33.5 \\
39.0 \\
38.0\end{array}$ & $\begin{array}{l}31.0 \\
29.5 \\
35.0 \\
33.0\end{array}$ & $\begin{array}{l}29.0 \\
32.0 \\
34.0 \\
33.0\end{array}$ \\
\hline $\begin{array}{c}\text { Thrombin time } \\
\text { (sec) }\end{array}$ & $\begin{array}{r}400 \\
200 \\
25 \\
5 \\
1 \\
0\end{array}$ & $\begin{array}{l}69.0 \\
25.0 \\
14.3 \\
13.0 \\
13.8 \\
13.0\end{array}$ & $\begin{array}{l}60.0 \\
41.0 \\
17.4 \\
18.5 \\
17.0 \\
14.0\end{array}$ & $\begin{array}{l}85.0 \\
71.5 \\
45.0 \\
32.0 \\
25.0 \\
15.0\end{array}$ & $\begin{array}{l}48.0 \\
32.5 \\
30.0 \\
16.0\end{array}$ \\
\hline $\begin{array}{c}\text { Thrombofax test } \\
(\mathrm{sec})\end{array}$ & $\begin{array}{r}400 \\
200 \\
25 \\
0\end{array}$ & $\begin{array}{r}185 \\
150 \\
80 \\
75\end{array}$ & $\begin{array}{r}275 \\
150 \\
75 \\
75\end{array}$ & $\begin{array}{l}75 \\
75\end{array}$ & $\begin{array}{l}75 \\
75\end{array}$ \\
\hline $\begin{array}{l}\text { Recalc. time } \\
\text { (sec) }\end{array}$ & $\begin{array}{r}400 \\
200 \\
25 \\
0\end{array}$ & $\begin{array}{r}90 \\
85 \\
100 \\
105\end{array}$ & $\begin{array}{r}80 \\
105 \\
140 \\
80\end{array}$ & $\begin{array}{l}65 \\
85 \\
75 \\
74\end{array}$ & $\begin{array}{r}83 \\
108 \\
63 \\
74\end{array}$ \\
\hline
\end{tabular}

insufficiency, the test may be a valuable tool for the detection of fibrinolytic hemorrhage and can be simply and rapidly done. However, no virtual cases of fibrinolytic hemorrhage tested by this method has been experienced in this Department.

\section{Determination of factors $\mathrm{V}$ and VIII}

As both factors V and VIII are also sensitively decreased in cases with hyperplasminemia, the determination of these factors is a valuable tool in diagnosis. The determination of factor $\mathrm{V}$ may be of practical importance if plasma deficient in factor $\mathrm{V}$ is kept in the laboratory.

8. Heparin tolerance test

The test was prolonged in 6 of 8 cases. The method and significance of this test will be detailed later by a co-workers, Kikuchi, elsewhere ${ }^{21)}$.

9. Recalcification time

The time was prolonged in 5 of 9 cases, and somewhat shortened in 3 cases.

10. Plasma fibrinogen titer (PFT) and fibrinolysis level

In this test, fibrin clot can be found over $1: 2^{8}$ dilution, and fibrinolysis cannot 
be observed below 1: $2^{7}$ in normal plasma. In 13 of 15 cases, PFT was abnormally low while the fibrinolysis level was elevated in 10 of 12 cases. If concentration of fibrinogen in plasma is low, the fibrinolysis level gives an apparently high value. For this reason, this method is chemically not precise, but it has an advantage in its simplicity.

\section{Fibrinogen}

The determination of fibrinogen is essential to make a diagnosis of hypofibrinogenemia, and it should be done as early as possible after the collection of the blood sample in order to prevent further fibrinogenolysis. If the determination is impossible soon after the sampling, it is preferable to add a small amount of epsilon aminocaproic acid (EACA) to the whole blood (add 5-10 mg of EACA to $1 \mathrm{ml}$. of blood). This addition of EACA in the determination of fibrinogen was first described by Maki et al. ${ }^{5}$ ) and supported by Nilsson and Olow ${ }^{22}$. However, as the fibrin formation by thrombin is slightly interfered with in the presence of EACA, it needs a somewhat longer time to completely form a fibrin clot than plasma without EACA.

TABLE IV. Changes of Plasmin System after Addition of SK to Plasma

\begin{tabular}{|c|c|c|c|c|c|c|c|}
\hline \multirow{2}{*}{ Test } & \multirow{2}{*}{$\begin{array}{l}\text { SK added } \\
\text { (units } / \mathrm{ml} \text { ) }\end{array}$} & \multicolumn{6}{|c|}{ Hours examined after SK addition } \\
\hline & & 5 & 30 & 60 & 120 & 180 & 240 \\
\hline $\begin{array}{l}\text { Fibrinogen } \\
\text { (Turbidometry, } \\
\text { OD) }\end{array}$ & $\begin{array}{r}400 \\
200 \\
25 \\
0\end{array}$ & $\begin{array}{r}0.060 \\
.342 \\
.400 \\
.395\end{array}$ & $\begin{array}{r}0.035 \\
.262 \\
.395 \\
.400\end{array}$ & $\begin{array}{r}0.032 \\
.052 \\
.372 \\
.400\end{array}$ & $\begin{array}{l}0.032 \\
.032 \\
.374 \\
.400\end{array}$ & $\begin{array}{r}.365 \\
.400\end{array}$ & $\begin{array}{l}.365 \\
.400\end{array}$ \\
\hline $\begin{array}{l}\text { Euglobulin } \\
\text { activity* } \\
\left(10^{-3} \text { units } / \mathrm{ml}\right)\end{array}$ & $\begin{array}{r}400 \\
200 \\
25 \\
5 \\
0\end{array}$ & & $\begin{array}{l}7.2 \\
6.5\end{array}$ & $\begin{array}{l}3.4 \\
3.2 \\
3.1 \\
1.0 \\
0.1\end{array}$ & $\begin{array}{l}1.2 \\
1.0 \\
0.4 \\
0.4 \\
0.1\end{array}$ & $\begin{array}{l}0.1 \\
0.1 \\
0.1 \\
0.1 \\
0.1\end{array}$ & $\begin{array}{l}0.1 \\
0.1 \\
0.1 \\
0.1 \\
0.1\end{array}$ \\
\hline $\begin{array}{l}\text { Total plasmin** } \\
\left(10^{-3} \text { units } / \mathrm{ml}\right)\end{array}$ & $\begin{array}{r}400 \\
200 \\
25 \\
5 \\
0\end{array}$ & & $\begin{array}{l}7.2 \\
8.5\end{array}$ & $\begin{array}{r}1.2 \\
4.0 \\
11.0 \\
14.0 \\
15.8\end{array}$ & $\begin{array}{r}1.0 \\
1.2 \\
9.2 \\
12.4 \\
16.0\end{array}$ & $\begin{array}{r}8.2 \\
8.8 \\
16.0\end{array}$ & $\begin{array}{r}8.0 \\
8.3 \\
16.0\end{array}$ \\
\hline $\begin{array}{l}\text { Slow inhibitor } \\
\left(10^{-2} \text { units } / \mathrm{ml}\right)\end{array}$ & $\begin{array}{r}400 \\
25 \\
0\end{array}$ & & & $\begin{array}{l}2.1 \\
3.0 \\
3.2\end{array}$ & $\begin{array}{l}2.8 \\
3.2\end{array}$ & $\begin{array}{l}1.7 \\
2.3 \\
3.2\end{array}$ & $\begin{array}{l}2.0 \\
3.0\end{array}$ \\
\hline $\begin{array}{l}\text { Immediate } \\
\text { inhibitor } \\
\left(10^{-3} \text { units } / \mathrm{ml}\right)\end{array}$ & $\begin{array}{r}400 \\
25 \\
0\end{array}$ & & & $\begin{array}{l}2.7 \\
3.2 \\
4.4\end{array}$ & $\begin{array}{l}0.9 \\
1.8 \\
4.4\end{array}$ & $\begin{array}{l}1.0 \\
4.3\end{array}$ & \\
\hline
\end{tabular}

* This activity was measured on the euglobulin fraction which was precipitated from the SK-added plasma. **This was done by the same way to the former but with further addition of SK to the obtained euglobulin. 
In vitro experiment showed that fibrinogen concentration determined by a turbidometric method of Parfentjev et al. was decreased in proportion to the amounts of SK added.

12. Thrombin time

In vitro experiment showed that the thrombin time was markedly and sensitively prolonged in proportion to the amounts of SK added. A significance of determination of the thrombin time has been regarded as an important diagnostic tool for this situation by Sharp et al. ${ }^{23)}$, Ingarm et al. ${ }^{24)}$, Fletcher et al. 25) and Beller ${ }^{26)}$. As thrombin time is influenced by a decrease of fibrinogen, qualitative change of fibrinogen (dysfibrinogenemia) and increase of anticoagulants such as heparin or depolymerization product of fibrinogen, it is not a specific test for the condition. Hougie ${ }^{3)}$ and von Kaulla ${ }^{27)}$ noted the significance of thrombin time in cardiac surgery with extracorpreal circulation. In actual cases, a marked prolongation of thrombin time (over 180") was observed in all of 3 .

13. Spontaneous proteolytic activities of euglobulin fraction

The spontaneous caseinolytic, fibrinolytic and fibrinogenolytic activities of the patient's euglobulin fraction showed a great range of values from normal to abnormally high. As noted previously ${ }^{28}$, spontaneous proteolytic activity of the euglobulin fraction showed a marked fluctuation from time to time. In general, there is a tendency to fall from a high level by the caseinolytic method when bleeding begins. In clinical cases of fibrinolytic hemorrhage, it is relatively rare to be able to detect high proteolytic activity of the native euglobulin, because the activated plasminogen (plasmin) is easily neutralized by the antiplasmin in the blood or destroyed spontaneously. A markedly high level of caseinolytic activity was noted in 2 cases (Cases 11 and 12) in which blood samples were drawn prior to manifestation of the hemorrhage. In the remaining 14 cases, 4 were slightly elevated and 10 were within normal limits. Even if the activity of euglobulin fraction obtained from a patient who has already bled is within normal limits, this value does not always mean a return to a physiologic normal. It is, therefore, possible to conclude that the normal value of caseinolytic activity has an alternative interpretation which is either genuine normal or an apparently false normal due to inactivation of produced plasmin. The slightly elevated spontaneous euglobulin activity may denote, in the same fashion, either a value under the process of initiation of plasminogen activation or under the process of inactivation of transformed plasmin. The differential diagnosis between them may be possible by the determination of total plasmin and antiplasmin as presented in Table V.

In vitro experiment could support adequately the interpretation of the 
Table V. Diagnosis of Results of Fibrinolytic Enzyme System Assay

\begin{tabular}{|c|c|c|c|}
\hline Method & \multicolumn{3}{|c|}{ Result } \\
\hline $\begin{array}{l}\text { Spontaneous proteolytic } \\
\text { activity of euglobulin } \\
\text { fraction }\end{array}$ & Normal & $\begin{array}{l}\text { Normal or slightly } \\
\text { elevated }\end{array}$ & Elevated \\
\hline Total plasmin & Normal & Decreased & $\begin{array}{l}\text { Normal or slightly } \\
\text { decreased }\end{array}$ \\
\hline Antiplasmin & Normal & Decreased & $\begin{array}{l}\text { Normal or slightly } \\
\text { decreased }\end{array}$ \\
\hline $\begin{array}{l}\text { Spontaneous fibrinolysis } \\
\text { of whole blood or plasma }\end{array}$ & Negative & Frequently positive & Positive \\
\hline Diagnosis & $\begin{array}{l}\text { Genuine } \\
\text { normal }\end{array}$ & $\begin{array}{l}\text { Inactivation process of } \\
\text { activated plasmin, or } \\
\text { evidence of previously } \\
\text { fibrinolysis elevation }\end{array}$ & $\begin{array}{l}\text { Process of elevation of } \\
\text { fibrinolytic activity }\end{array}$ \\
\hline
\end{tabular}

clinical results. Namely, a gradual loss of plasmin activity of the euglobulin fraction, obtained from artificially induced fibrinolytic plasma, was noted while allowing it to stand.

The fibrinolytic activity of the euglobulin fraction was elevated in 6 of 12 cases and fibrinogenolysis in 8 of 11. An interesting fact was that the fibrinogenolytic activity exceeded the fibrinolytic activity in 8 of 11 cases. This is contrary to the general property of plasmin which has an ability to hydrolyze fibrin more rapidly than fibrinogen. It is unknown why such a reversal is frequently found in cases of fibrinolytic hemorrhage.

\section{Total plasmin}

Sometimes, one is apt to fall into the erroneous thought that the total plasmin, proteolytic activity of the SK-activated euglobulin, increases in such cases as fibrinolytic hemorrhage. However, a decrease of total plasmin was noted in all 6 cases of fibrinolytic hemorrhage. This decrease seems to be caused by consumption of plasminogen due to previously occurring plasminogen activation ${ }^{25,29,30}$.

15. Antiplasmin

A decrease of antiplasmin activity was noted in all 4 cases with fibrinolytic hemorrhage.

In vitro experiment gave a marked decrease of immediate inhibitor, but only a slight decrease of slow inhibitor. Maki ${ }^{31)}$ noted that the decrease of antiplasmin may be one of the etiologic factors of fibrinolytic hemorrhage. Stamm ${ }^{32}$ ) also noted in his publication that fibrinolysis with coagulation defects accompanies the decrease of antiplasmin.

16. Thrombelastography

Fig. 1-A shows a typical fibrinolytic thrombelastogram found in a patient 


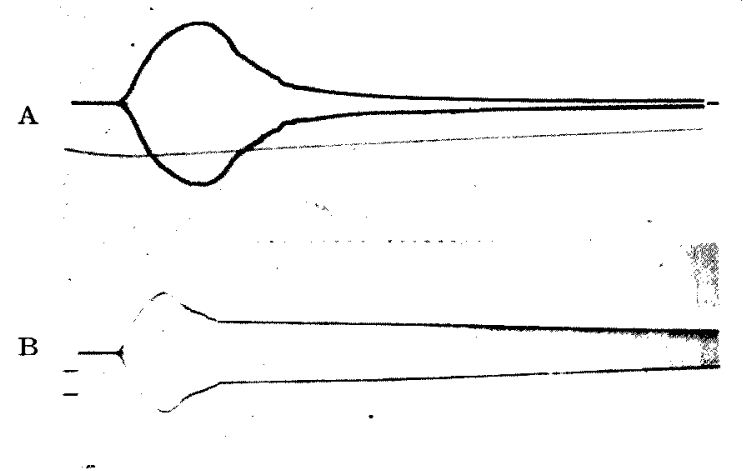

Fig. 1. Fibrinolytic thrombelastograms.

undergoing simple hysterectomy for uterine fibroid. Fig. 1-B also shows an elevated fibrinolytic state, in which progress of fibrinolysis was interrupted. Such an interruption of the further advance of fibrinolysis may be caused by inactivation of plasmin under the influence of inhibitor, especially slow inhibitor.

17. Erythrocytes sedimentation rate (ESR)

As fibrinogen concentration influences the ESR, it will be lowered in cases of hypofibrinogenemia. In fact, a markedly lowered ESR was noted in all 6 cases of obstetric hypofibrinogenemia as compared with the accelerated ESR of normal pregnancy. In vitro experiment supported this mechanism ${ }^{33)}$. The determination of ESR is one of the routine tests of parturient woman in authors' clinic. If a lowered ESR is noted in pregnant woman, the patient may have a decreased fibrino-

TABLE VI. Influence of Fibrinogen and SK Addition on $\operatorname{ESR}(\mathrm{mm}$, one hour rate)

\begin{tabular}{l|c|c|c|c|c}
\hline & $\begin{array}{c}\text { Healthy } \\
\text { male }\end{array}$ & Pregnant & Pregnant & Pregnant & $\begin{array}{c}\text { Cervix } \\
\text { cancer }\end{array}$ \\
\hline Original citrated blood & 4 & 34 & 25 & 48 & 25 \\
$\begin{array}{l}\text { SK addition* } \\
\text { Human fibrinogen } \\
\text { add.** }\end{array}$ & 2 & 8 & 7 & 10 & 18 \\
$\begin{array}{l}\text { Fibrinogen, SK } \\
\text { add.*** }\end{array}$ & 25 & 115 & 73 & 110 & \\
\end{tabular}

* To $2 \mathrm{ml}$. of citrated blood, one drop of SK $(100,000$ units $/ \mathrm{ml})$ was added, and then ESR measured.

** Human fibrinogen $(100 \mathrm{mg}$ ) was dissolved in $2 \mathrm{ml}$. of citrated blood.

*** The above fibrinogen-added blood was treated with one drop of SK.

gen concentration as compared with a normal pregnant woman who should have high fibrinogen concentration and an elevated ESR. But this is not applicable in non-pregnancy with a normal fibrinogen level. 


\section{Liver function}

As the liver is said to be a main organ producing clotting factors, a liver function damage may cause a hemorrhagic diathesis. Positive CCF test was specifically noted in 12 of 13 cases of fibrinolytic hemorrhage. It is unknown why the CCF test is the only one specifically positive.

From the above observations, the determination of clotting time, clot-lysis time of the whole blood and plasma, fibrinogen by PFT method and turbidometric method, partial thromboplastin time by Thrombofax, thrombin time, ESR in obstetrical cases and thrombelastography seem to be valuable tools because of their simplicity and the rapidity of the tests. The determination of fibrinogen by colorimetric method and plasmin system are essential to make a diagnosis of fibrinolytic hemorrhage. Prothrombin time activity by TAMe-lytic method and liver function test are also useful. However, as these tests are time-consuming and complicated in technique, therapeutic procedure may often be initiated before ascertaining the laboratory values.

Of course, such basic diseases which may result in fibrinolytic hemorrhage, as obstetrical abnormalities, surgical operations, especially surgery of the lung, prostatic gland, heart and malignant tumors are of importance as well as symptoms characterized by endless bleeding oozing or uncontrollable hemorrhage.

\section{References}

1) Maki M., Tohoku J. exp. Med., 1962, 78, 264.

2) Glueck, H.I., Sherry, S. \& Troll, W., Proc. Soc. exp. Biol., 1954, 87, 646.

3) Hougie, C., Acta haemat., 1960, 24, 135.

4) Nye, S.W., Graham, J.B. \& Brinkhouse, K.M., Amer. J. med. Sci., 1962, 243, 279.

5) Maki, M., Kikuchi, E. \& Sato, T., Jap. J. Obstet. Gynec. (Jap.), 1961, 13, 1801.

6) Parfentjev, I.A., Johnson, M.L. \& Cliffton, E.E., Arch. Biochem., 1953, 46, 470.

7) Maki, M., Tohoku J. exp. Med., 1963, 81, 179.

8) Maki, M., Saito, H. \& Yoneya, T., ibid., 1964, 83, 168.

9) Hanger, J., J. clin. Invest., 1939, 18, 261.

10) Deutsch, E. \& Elsner, P., Amer. J. Cardiol., 1960, 6, 420.

11) Baker, S.J. \& Jacob, E., J. clin. Path., 1960, 6, 420.

12) Nolan, R.K. \& Frick, P.G., Obstet. and Gynec., 1953, 32, 508.

13) Hsu, C.T., Ma, Y.M., Wang, T.T., Chen, C.C., Fu, C.C., Wei, S.C., Liu, C.H., Sheu, Y.S. \& Ouyang, C.H., Amer. J. Obstet. Gynec., 1960, 80, 263.

14) Sharp, A.A., Howie, B., Biggs, R. \& Metuhen, D.T., Lancet, 1958, 7960, 1309.

15) Firkin, B.G., Reed, C.S.H. \& Blackburn, C.R.B., Brit. J. Haemat., 1957, 3, 193.

16) Johnson, S.A. \& Schendier, C.L., Science, 1953, 117, 229.

17) Ikami, H., Ohe, S., Nakagawa, M., Sumiyoshi, T., Tojo, J., Ueno, N., Nishijima, N., Suzuki, H. \& Sakai, A., Rinsho-Naika-Shonika (Jap.), 196, 15, 648,

18) Bronzman, M., Zbl. Gynaek., 1961, 83, 1167.

19) Maki, M., Jap. J. Obstet. Gynec. (Jap.), 1964, 15, 13.

20) Langdell, R.D., Wagner, R.H. \& Brinkhous, K.M., J. Lab. clin. Med., 1953, 41, 637.

21) Kikuchi, I., Will be contributed to this Journal.

22) Nilsson, I.M. \& Olow, B., Acta chir. Scand., 1962, 123, 247. 
23) Sharp, A.A., Howie, B., Biggs, R. \& Metuhen, D.T., Lancet, 1948, 7060, 1309.

24) Ingram, G.I.C., Norris, P.R. \& Tanner, E.I., J. Obstet. Gynaec., 1960, 67, 1960.

25) Fletcher, A.P., Alkjaersig, N. \& Sherry, S., J. clin. Invest., 1962, 41, 896.

26) Beller, F.K., Personal communciation.

27) Von Kaulla, N., Acta haemat., 1960, 24, 135.

28) Maki, M. \& Nagasawa, K., Tohoku J. exp. Med., 1963, 80, 315.

29) Todd, J.S. \& Phillips, L.L., Surg. Gynec. Obstet., 1962, 114, 333.

30) Maki, M., Tohoku J. exp. Med., 1963, 81, 179.

31) Maki, M., Jap. J. Obstet. Gynec. (Jap.), 1963, 15, 1207.

32) Stamm, H., Einfuehrung in die Klinik der Fibrinolyse, S. Karger, 1962.

33) Maki, M., Igaku no Ayumi (Jap.), 1964, 48, 105. 